\title{
Correspondence Analysis for Recognition of Facies in Homogeneous Sediments off an Iranian River Mouth
}

Marthe Melguen ${ }^{1}$

\section{ABSTRACT}

Six sediment cores from the submarine delta of the Rud Hilla River in the northern part of the Persian Gulf consist of fine grained, homogeneous Holocene marls. The coarse $(>63 \mu)$ fraction varies from $0.3-3.5 \%$. The cores are $2-4 \mathrm{~m}$ long and were taken in water depths of $8-56 \mathrm{~m}$. In spite of the great similarity and homogeneity of the cored sediments, correspondence analysis (an extension of factor analysis) of the coarse fraction reveals the presence of four distinctive sedimentary facies: (1) a minerogenic facies, $10 \mathrm{~km}$ from the estuary; (2) an ophiuroidostracod facies near a lateral margin of the delta, $12-15 \mathrm{~km}$ from the estuary, (3) a benthic foraminiferal-molluskan facies, in the central part of the delta $20 \mathrm{~km}$ from the estuary, and near its seaward margin $120 \mathrm{~km}$ from the estuary, (4) a gastropod-epibiotic facies, in an area of relatively slow sedimentation on the border of the delta, $90 \mathrm{~km}$ from the estuary. A seventh core, taken near the seaward margin of the delta of the Rud Hilla River, penetrated homogeneous, aragonite-rich mud of late Pleistocene age. Correspondence analysis of the sand fraction of the Pleistocene sediments leads to the definition of two facies that can be readily compared with the facies identified in the Holocene cores.

\section{INTRODUCTION}

The Rud Hilla River flows out of Iran into the northern Persian Gulf (fig. 1). Seaward of the estuary, a submarine delta extends to the SE, parallel to the coast (Sarnthein, 1971; fig. 2). The delta is approximately $120 \mathrm{~km} 1$ ong and $40 \mathrm{~km}$ wide. Seven gravity cores, $2-4 \mathrm{~m}$ in length, were taken in the area of the delta from the German oceanographic vesse1 "METEOR" during the 1964-1965 International Indian Ocean Expedition (Dietrich et al., 1966). Six of the cores are very similar in appearance and consist of fine grained, apparently homogeneous, Holocene sediments (fig. 3). The seventh core ( 1115 ; fig. 1), $2 \mathrm{~m}$ long and taken on the outer edge of the delta, contains whitish, late Pleistocene (approximately 12500 - 10000 years b.p.), aragonite-rich mud underlying Holocene green marls (fig. 3).

The purpose of the study reported in this paper was to investigate sedimen- 2 tary history in the Rud Hilla delta area by looking for, and defining, different facies

1 Geologisch-paleontologisches Institut und Museum der Universitat Kie1 40-60 01shausenstrasse, $23 \mathrm{KIEL}$

Present adress: Centre Océanologique de Bretagne, B.P. 337, 29 N BREST, France.

2 "assemblage of physical and organic characteristics ... that indicate conditions of deposition" (Moore, 1949). 
within the cores (Melguen, 1971). ${ }^{1}$ The apparent homogeneity of the sediments indicated that this would require a method of considerable sensitivity. Shepard and Moore (1954) suggested that: "coarse-fraction studies appear to provide one of the best means of differentiating modern environments, and give important evidence of distances from shore, and water depths. It is thought that the method could be applied to help differentiate environments of ancient sediments". Sarnthein (1971) utilised modifications of Shepard and Moore's procedures for his study of sand fractions of surface sediment samples from the Persian Gulf. The author, proceeding from a similar approach, has used correspondence analysis (an extension of standard factor analysis) for the statistical processing of the data derived from detailed microscopic analyses of coarse $(>63 \mu)$ fractions.

The results show that it is possible to identify distinctive facies within the six homogeneous Holocene cores from the Rud Hilla delta and thereby to gain some insight into recent changes in the history of sedimentation in this part of the Persian Gulf. Identification of the late Holocene facies also permits a better recognition of differences between the Holocene sediments and those of the sequence containing late Pleistocene sediments that were cored on the south-western margin of the delta (core 1115; fig. 1).

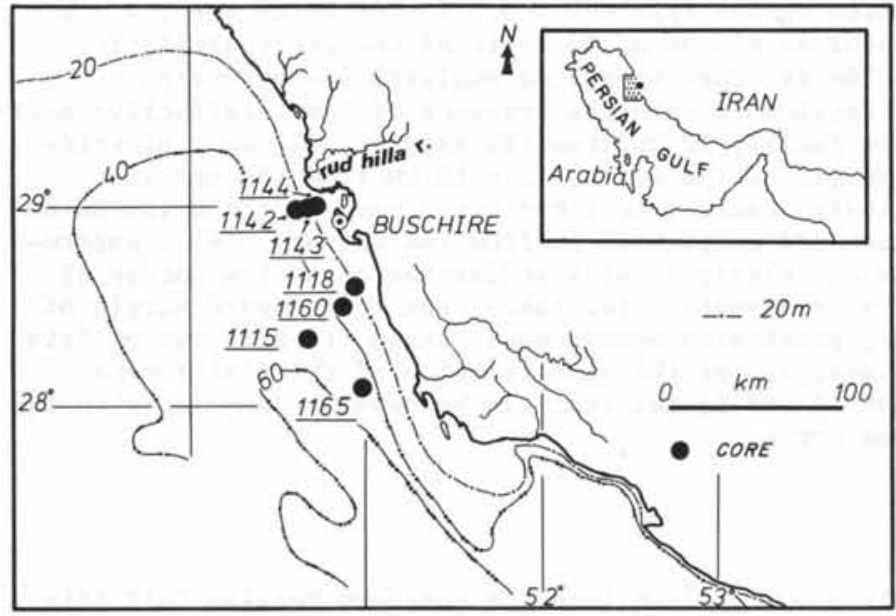

Fig. 1. Location of gravity cores taken in the Rud Hilla delta area in the northern part of the Persian Gulf

1 Full results are to be published in "Meteor" Forsch. Ergebnisse. 


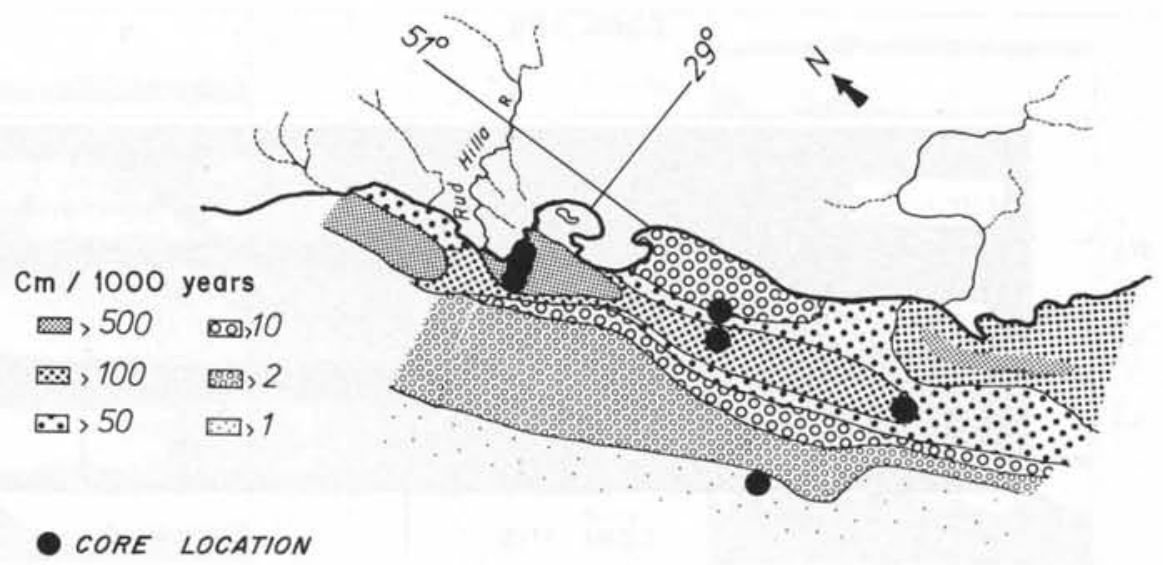

Fig. 2. Map showing approximate sedimentation rates in the Rud Hilla delta area, northern Persian Gulf (after Sarnthein, 1971)

\section{ANALYTICAL METHOD}

Sampling the seven cores (table 1) at about $2-7 \mathrm{~cm}$ intervals throughout their length provided 139 specimens for study. The sand fractions $(2000-63 \mu)$, separated by wet sieving, constitute $0.3-3.5 \%$ by weight of total sediment.

Each sand fraction was divided by dry sieving into five grain-size classes: $2000-1000 \mu, 1000-500 \mu, 500-250 \mu, 250-125 \mu, 125-63 \mu$. Six hundred and ninety five subsamples were thus obtained. Between $800-1000$ particles within each subsample were identified under the binocular microscope (Plas et al., 1965) and each particle was assigned to one of 33 different components (e.g. pteropods, echinoids, biotites) within various categories of components (e.g. total benthic components, total terrestrial components; fig. 4 - 5).

The information generated by the above procedures provides the basis for the recognition of facies in the cored sediments. The array of data is large and well suited for statistical treatment.

Several authors have used factor analysis in paleontological and sedimentological studies (Imbrie et al., 1962, 1964; Briggs, 1965; Klovan, 1966; Osborne, 1969; Kelley et al., 1969; Allen et al., 1970; Beall, 1970). In factor analysis, clouds of observation points in variable space (or of variable points in observation space) are examined by use of privileged axes (factorial axes or factors) which best define the approximate shape of the cloud. 
CORE 1118
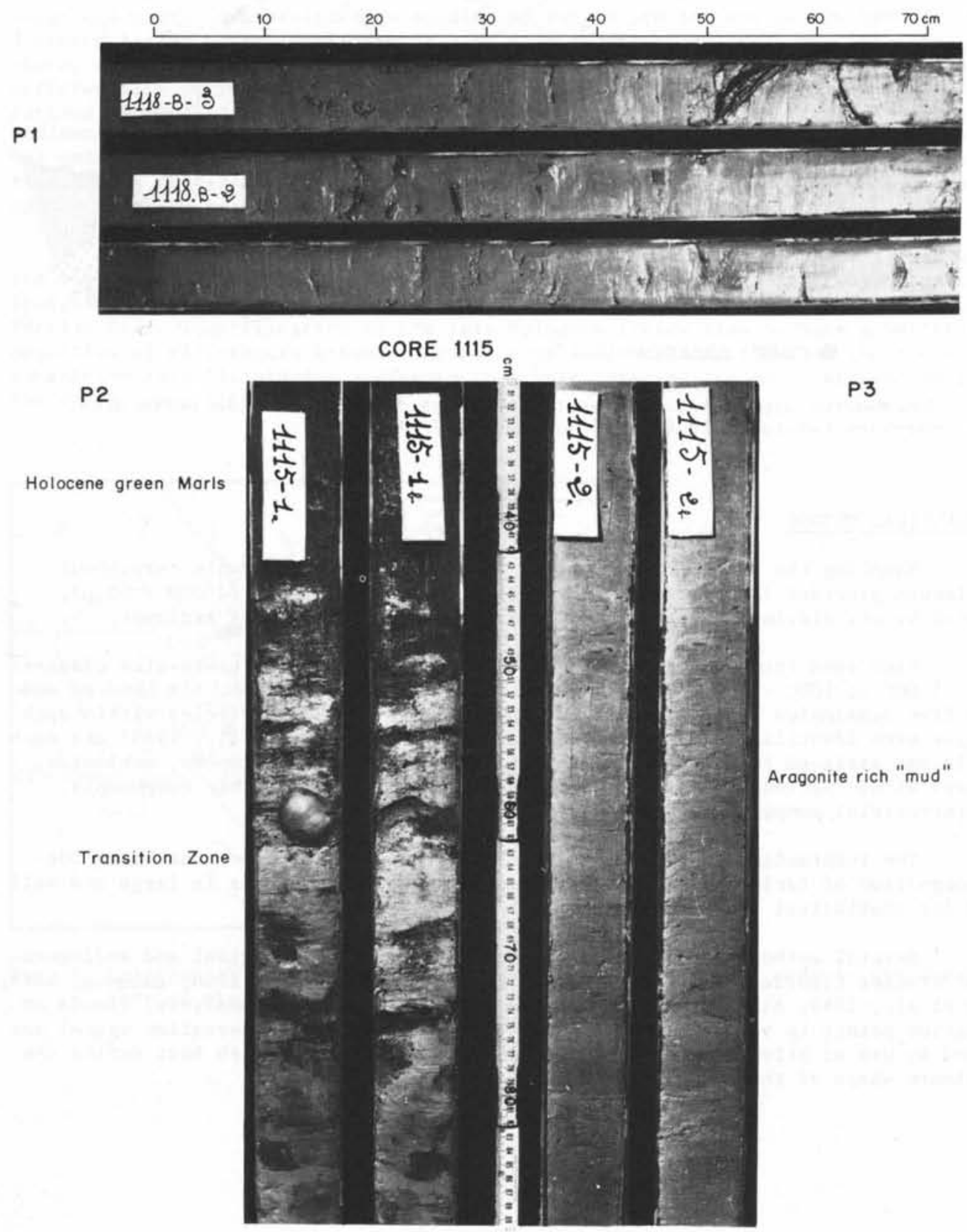

Fig. 3. Photographs of sections of cores 1118 and 1115; delta region of the Rud Hilla River, northern Persian Gulf 


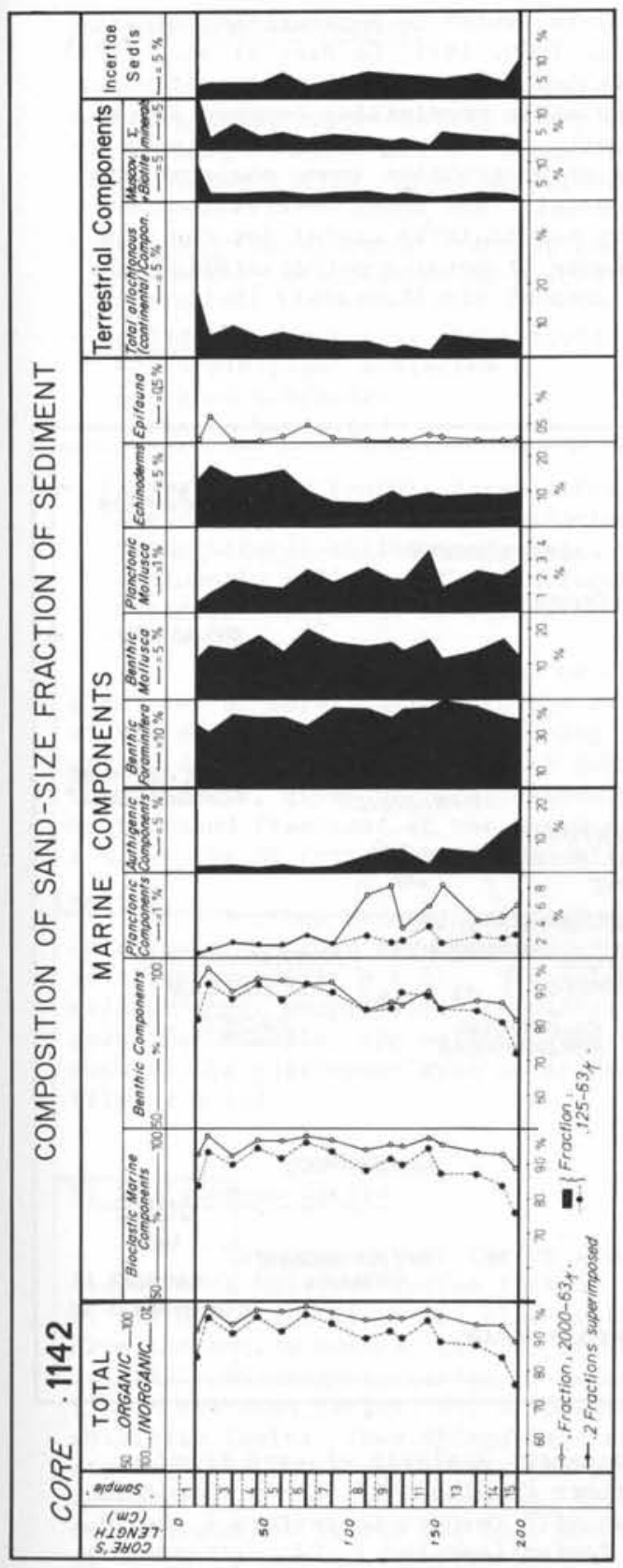

Fig. 4. Composition of sandsize fraction in sediment core 1142; Rud Hilla delta, northern Persian Gulf. The percentages are percentages of total sand fraction

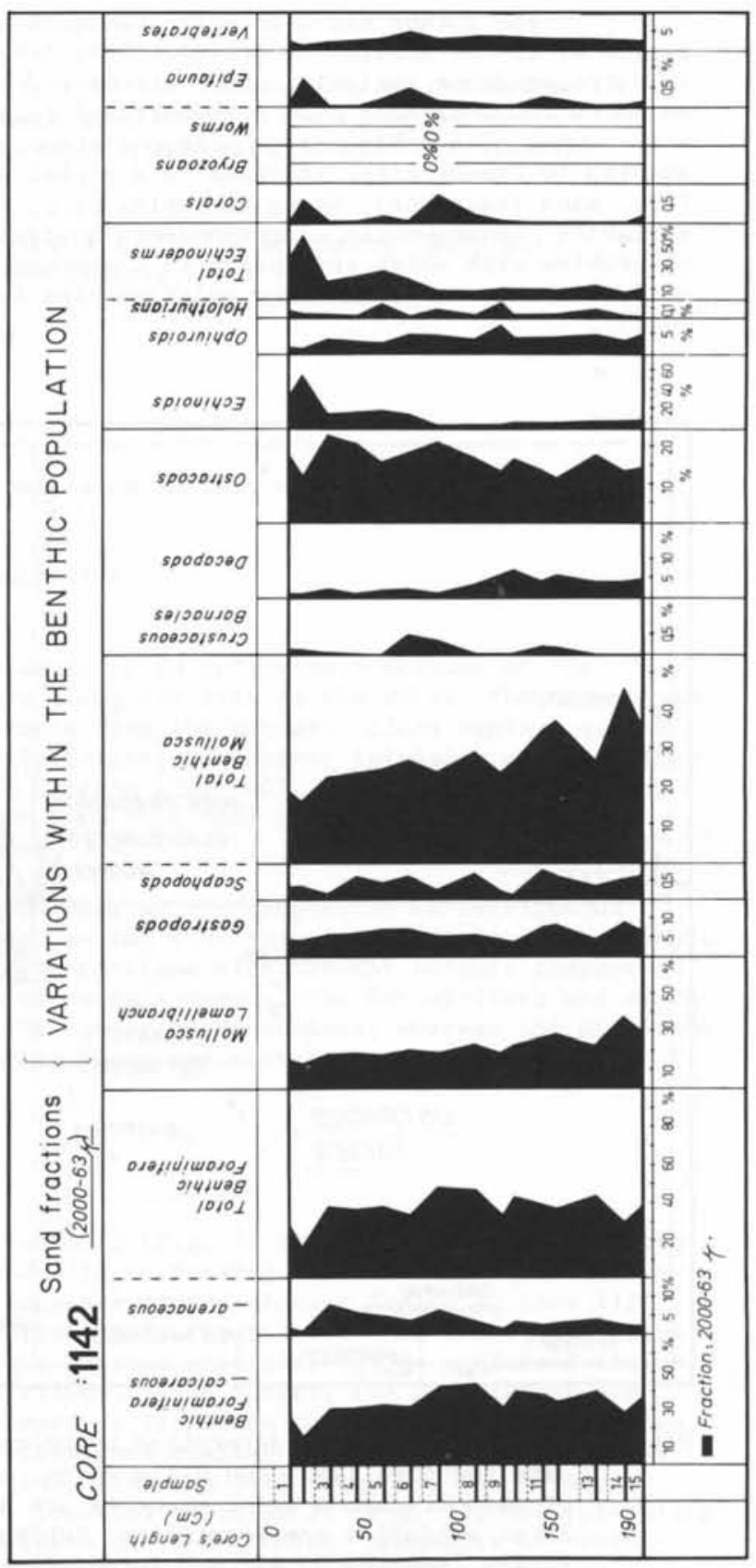

Fig. 5. Distribution of sandsize benthic components of the sediments of core 1142; Rud Hilla delta, norther Persian Gulf. The frequencies are calculated as percentages of the total benthic population 
The author has used correspondence analysis, which is Benzecri's generalization of factor analysis (Cordier, 1965; Benzecri, 1970, 1971; Le Bart et al., 1971). In correspondence analysis, observations and variables (which need not be continuous as in factor analysis) play a symmetrical role. Possible proximities between lines and columns of a table can be measured simultaneously. Correspondence analysis is adapted to frequencies. It leads to a global view of proximities among observations (i.e. sand fractions), among variables (i.e. components) and among observations and variables. Consequently, correspondence analysis is particularly useful for the type of problem with which this paper is concerned because it permits a characterization of facies that takes numerous relationships into account simultaneously (Melguen, 1972).

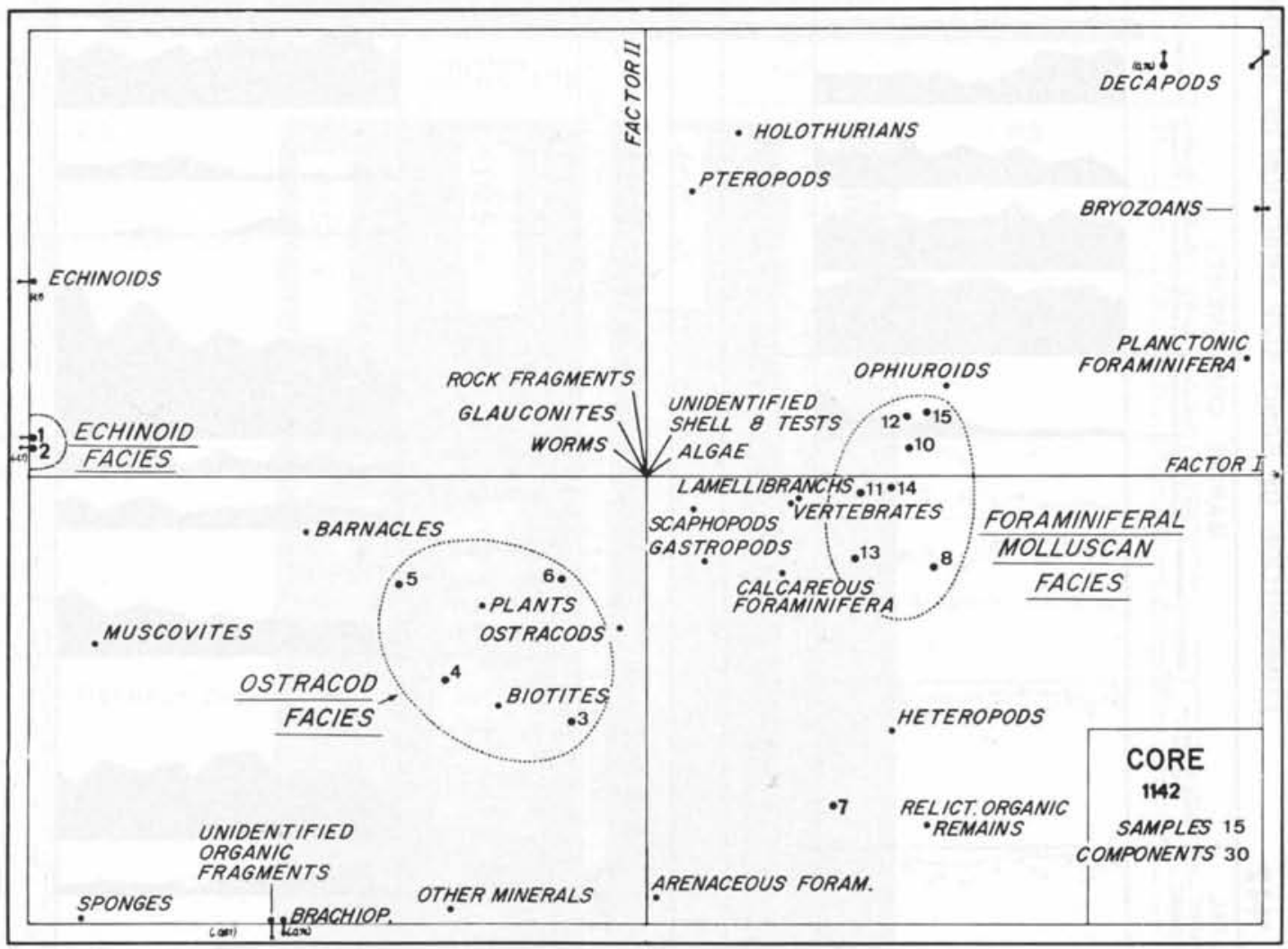

Fig. 6. Sedimentary facies determined by correspondence analysis of sand fraction data for core 1142; Rud Hilla delta, northern Persian Gulf. The proximities of sand fractions and components are shown with respect to factors I and II. Three subfacies are identified: Echinoid facies (samples 1, 2); ostracod facies (samples 3,6); and foraminiferal-molluscan facies (samples 8, ... 15)

\section{RECOGNITION AND DISTRIBUTION OF FACIES}

Six facies (I - VI) of Rud Hilla delta sediments are recognized by correspondence analysis (fig. 6, 7 and 8 ). They can be grouped into 3 late Holocene facies (I, II, III), which include a total of 9 subfacies; 2 Pleistocene facies (V - VI); and one transitional, early Holocene facies (IV). 


\section{a) Late Holocene facies}

The late Holocene facies (I, II, III) are represented by the sediments occuring today approximately along the axis of the Rud Hilla submarine delta, from the estuary towards the SE (cores 1144, 1142, 1160, 1165). Their distribution along factor I (fig. 7) is as follows:

- facies I: minerogenic ${ }^{1}$ facies, comprising a subfacies of quartz ${ }^{2}$, feldspar, followed by a subfacies of muscovite and biotite.

- facies II: comprising three subfacies:

ophiuroid-plant subfacies

ostracod subfacies

echinoid subfacies

- facies III or benthic foraminiferal-molluskan facies, comprising four subfacies: dominantly foraminiferal subfacies

foraminiferal-molluskan facies

dominantly molluskan lamellibranch subfacies

gastropod-epibiotic subfacies

Factor I (fig. 7) may be considered as an approximate measure of the distances of core stations to the estuary along the axis of the delta. The composition of the sand changes with increasing distance from the estuary: micas replace quartz and feldspar; frequency of plant debris increases; muscovite, initially more prominent than biotite, gives way progressively to biotite (fig. 10). The terrigenous content of the sand fractions of the cores ranges from $80 \%$ near the estuary to less than $1 \%$, at the SE extremity of the delta (fig. 10).

Benthos becomes increasingly abundant as the proportion of terrigenous detritus diminishes and hence, presumably, as the environmental conditions for benthic life improve (fig. $9 \& 11$ ). The relative proportions of different benthic components reflect their adaptability to different microenvironments. The Foraminifera and ostracods, for example, are we11 adapted to the estuarine conditions, whereas the organisms such as the gastropods seem to prefer areas where sedimentation rates are slower (fig. $2 \& 11$ ).

\section{b) Pleistocene facies}

The sequence of facies along factor I (Fig. 7) corresponds not only to the sequence of Holocene facies that is found with increasing distance from the estuary of the Rud Hilla River but also to the sequence of Pleistocene facies in core 1115 . From the bottom towards the top of core (factor I; Figs. $7 \& 8$ ) are found successively: (1) a minerogenic facies of quartz and various minerals, (2) an ophiuroid facies (3) an ostracod facies, (4) a foraminiferal-molluskan facies, (5) a gastropod and epibiotic facies. Thus, things have developed as if, since the end of the Pleistocene, station 1115 had successively occupied situations similar to those now respectively characteristic of stations 1144, 1143, 1142, 1160 and 1118 (Fig. 9). The Holocene and Pleistocene facies are not, however, identical. Factor II (Fig. 7), interpretation of which is complex (section IV.b), indicates the differences: fragments of resedimented rocks, micas and plants not as abundant at station 1115; epifauna (worms, bryozoans) and pellets, very abundant at station 1115 .

1 with minerals as major components.

2 The Rud Hill River today drains mainly Tertiary and Quaternary sandstone marls, limestones and evaporites. (Sampo, 1969). 


\section{SEDIMENTARY HISTORY}

The evidence of the identity and distribution of facies in the cores from the Rud Hilla delta makes it possible to attempt a reconstruction of sedimentary history in the area. The author has, during the course of this study, maintained the view that observations of the more recent sediments are a necessary starting point for the interpretation of the Pleistocene facies, and the late Holocene sediments are

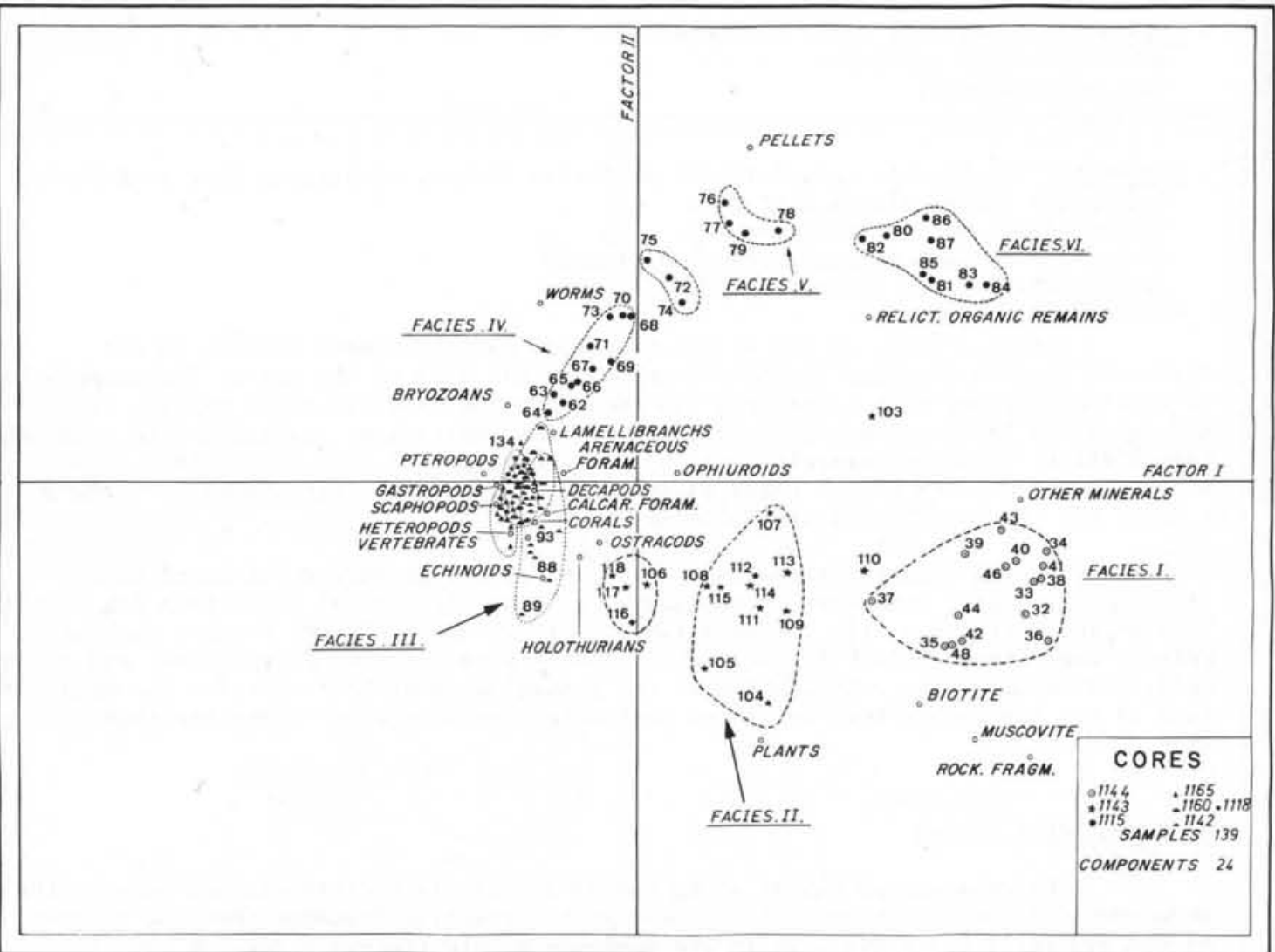

Fig. 7. Sedimentary facies determined by correspondence analysis of sand fraction data for 7 cores from the Rud Hilla delta in the northern part of the Persian Gulf. The matrix was constituted by the frequencies of components in the cotal sand fraction of each sample. The proximities of sand-fractions and components are shown with respect to factors I and II. Analysis of the proximities leads to the identification of 6 facies: 3 late Holocene facies (I, II, III), 2 late Pleistocene-early Holocene facies (V, VI), 1 transitional facies

\section{discussed first.}

\section{a) Late Holocene}

Sedimentation rates seem to be the main control of facies distribution in the Rud Hilla delta environment. Tentative estimates of sedimentation rates for the depositional periods represented by each subfacies (table 3 ) are based on a series of C 14 datations (table II) and on other evidence of present day sedimentation patterns in the area (Sarnthein, 1971). 
The depositional history of the delta has tended to be characterized by an increase in the rate of sedimentation since approximately 6000 B.P.. The increase is accompanied at stations 1142, 1143, 1118 (Fig. 9) by an evolution of sedimentary subfacies that includes: (1) the appearance of the minerogenic sub-facies at the top of core 1143, (2) an upward change from foraminiferal sub-facies to ostracod sub-facies, to echinoid sub-facies in core 1142, and (3) an upward change from gastropod and epibiotic sub-facies, to molluskan (lamellibranch) facies, to foraminiferalmolluskan sub-facies in core 1118 .

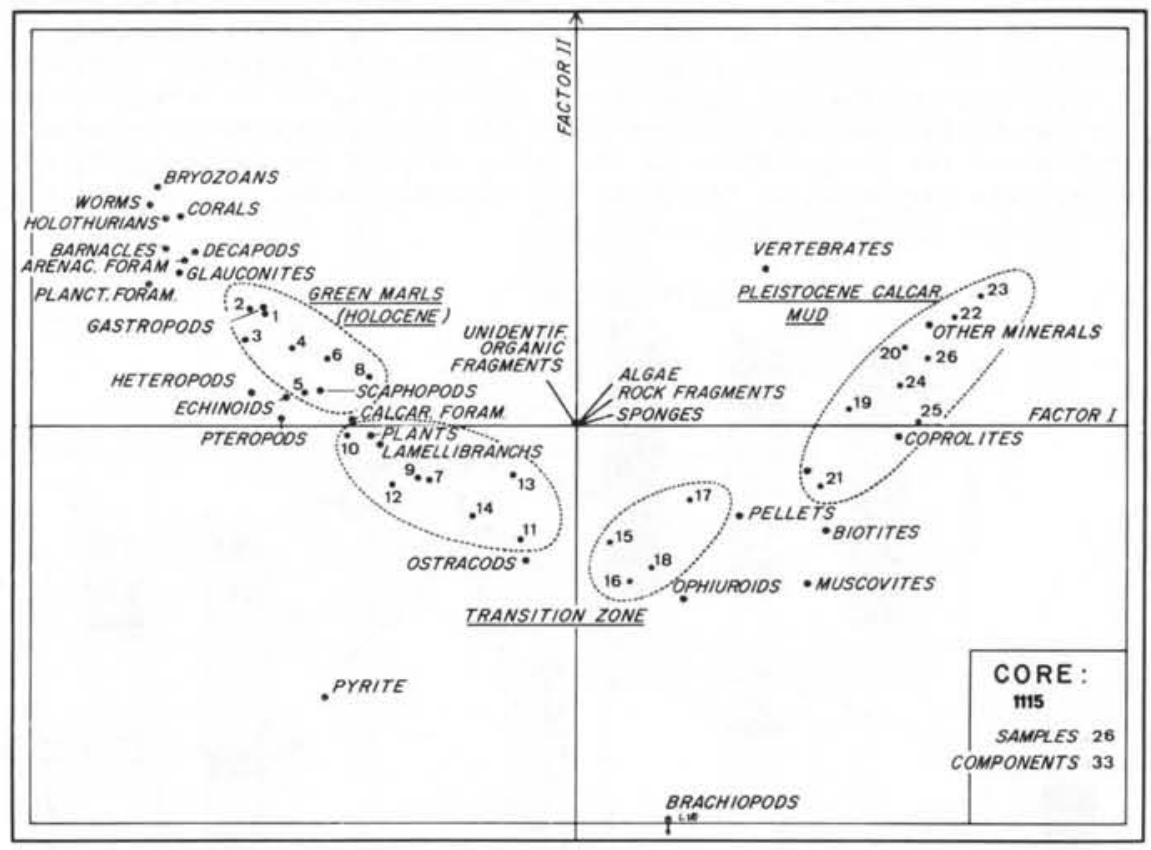

Fig. 8. Sedimentary facies determined by correspondence analysis of core 1115; Rud Hilla delta, northern Persian Gulf. Along factor I (from right to left in the diagram, that is, from bottom to top of the core, the following facies are recognized: (1) late Pleistocene facies, (2) transition facies, namely ophiuroid sub-facies and ostracod sub-facies, (3) early Holocene facies including gastropod-epibiotic sub-facies

The increased rate of sedimentation seen at stations 1143, 1142, 1118 (Fig. 9) cannot be traced across the entire delta. Core 1160 (Fig. 9) is almost homogeneous from top to bottom, sedimentation over the past 6000 years being represented principally by one sub-facies (facies III c). Sedimentation was interrupted by three minor depositional events associated with slightly higher sedimentation rates, and with accumulation (perhaps by decapods) of shell fragments (subfacies III b).

In addition to the question of sedimentation rates, there have evidently been changes of sediment distribution over parts of the delta. Core 1165 (Fig. 9) exhibits a sequence that is evident1y the inverse of core 1160: the estuarine subfacies at the bottom (subfacies III a) is followed by a foraminiferal-molluskan subfacies (subfacies III c), suggesting a decrease in the rate of sedimentation. It seems that sediment distribution on the Rud Hilla delta during the late Holocene was displaced towards the center of the gulf: this would explain why stations 1160 and 1165 have not been affected by the increase in the rate of sedimentation. 
Core 1118 (Fig. 9), the facies of which reveals a marked vertical evolution, suggests an increase of the sedimentation rate. It should, however, be noted that core 1118 was taken near the landward margin of the delta. Sedimentary evolution in this area is dependent on a terrigenous supply derived not only from the Rud Hilla River but also transported, probably by currents, from the adjacent coast.

Increases in the rate of sedimentation on the Rud Hilla delta during the last 6000 years could be the result of any one, or more, of the following processes: (1) the general increase in rainfall which affected Iran during the Holocene (Bobek, 1963, 1969; Butzer, 1966; Diester, 1972; Van Zeist and al., 1963: Van Zeist, 1967); (2) varying distribution of rainfall; less frequent but heavier precipitation would result in more violent run-off and consequently in an increased supply of terrigenous material; (3) destruction of vegetation leading to increased erosion; (4) displacement of the course of the Rud Hilla River, perhaps related to irrigation activities. Whatever the various causes may have been, the increased rate of erosion and sedimentation accelerated the progradation of the delta towards the central part of the gulf, together with migration of facies in the same direction.

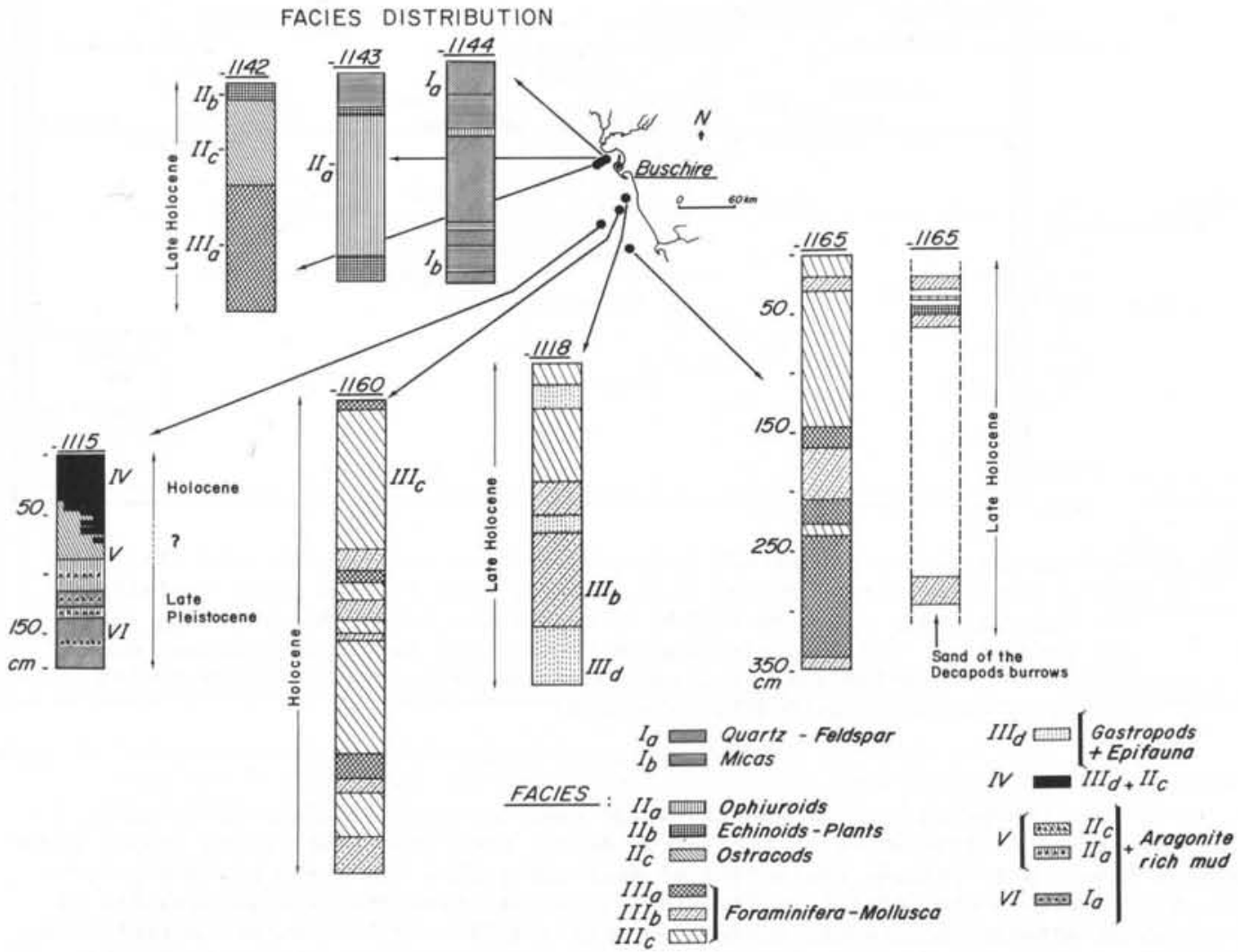

Fig. 9. Distribution of facies in 7 cores taken in the delta area of the Rud Hilla River in the northern Persian Gulf. Al1 the cores, except 1115, have the appearance of extreme homogeneity

\section{b) Late Pleistocene-early Holocene}

Some interpretation of sedimentary history in the present Rud Hilla delta area near the end of the Pleistocene (approx. 12,500-9,500 y. B.P.: table II) can be based on the study of the sediments penetrated at station 1115 (Fig. 1), where the Holocene is relatively thin. 

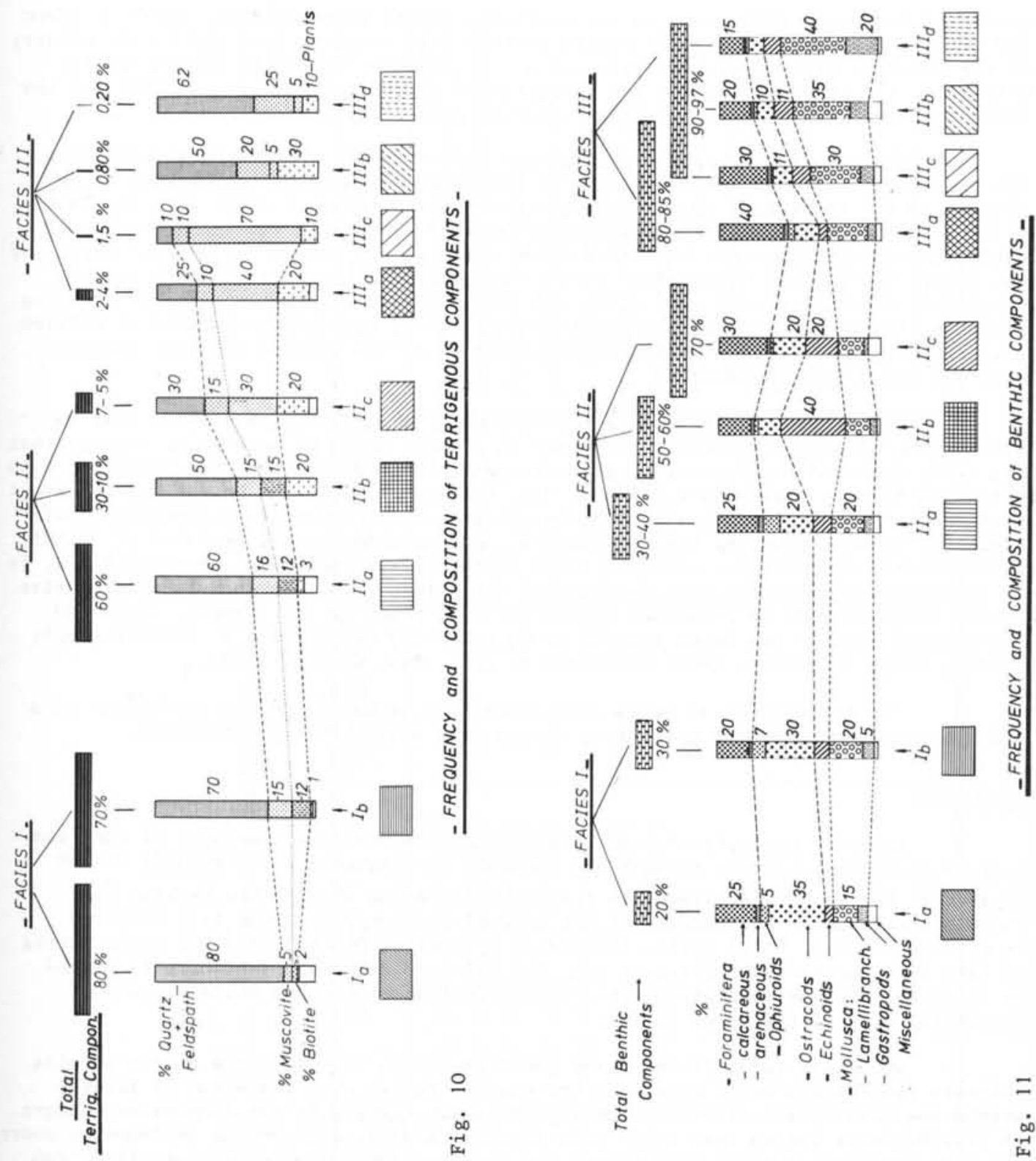

Fig. 10. Nature and frequency of the terrigenous components of the sand fractions identified in the cores taken in the delta area of the Rud Hilla River, northern Persian Gulf

Fig. 11. Nature and frequency of benthic components of the sand fractions (corresponding to each type of facies or subfacies), identified in the cores taken in the delta area of the Rud Hilla River, northern Persian Gulf

The main contrasts between the Pleistocene and Holocene sediments (section III) could have resulted from several environmental differences. The deposition of whitish, aragonite-rich mud may have reflected more favourable climatic conditions (Melguen, 1971). The smaller accumulation of micas and plants may have been a conse- 
quence of increased turbulence in the overlying waters (Paremancblum, 1966). A 1ower sea level would have effectively placed station 1115 close to land and to the estuary of the Shatt-a1-Arab river, now situated at the northern extremity of the Persian Gulf (Fig. 1), thus influencing the depositional environment at station 1115 and the provenance and transportational history of the accumulating sediments.

The relative importance of various environmental changes notwithstanding, the upward evolution of facies within the Pleistocene sediments corresponds quite closely to the successive changes of late Holocene facies that occur with increasing distance from the sedimentary source (section III). Core 1115 was taken in $56 \mathrm{~m}$ of water, about $90 \mathrm{~km}$ from the Rud Hilla River estuary, and beyond the present margin of the delta, whereas the Pleistocene facies recognized in the core (Fig. 9) suggest deposition in about $8-25 \mathrm{~m}$ of water and about $10-20 \mathrm{~km}$ from an estuary. Assuming that the estuary was that of the Shatt-al-Arab river, the sediments cored at station 1115 thus appear to represent increasing distance of the station from the estuary near the end of the Pleistocene.

The abrupt change from late Pleistocene, aragonite-rich deltaic muds to a green marl facies, apparently deposited in a water depth of 40 - $60 \mathrm{~m}$, suggest that the early Holocene transgression was very rapid. The deposition of the green marls is estimated to have begun about 9500 y. B.P. (Diester, 1972). The change may represent a sedimentary discontinuity although the pattern of transgressive sedimentation off Buschire, deduced from the facies analysis, and confirmed by the presence of benthic foraminiferal species that indicate water depths (Lutze, personnal communication), is in satisfactory agreement with established eustatic curves that show (1) a slow rise of sea level from 50 to 38 meters 12000 to 9000 years (B.P.) (Morner, 1966) and (2) a rapid rise of sea level from 38 to $20 \mathrm{~m}$ about 9000 years B.P. (Morner, 1969; Curray, 1961; Jelgersma, 1961; Schofield et a1., 1964; Cullen, 1967).

The termination of green marl deposition is marked by the appearance of a gastropod-epibiotic facies indicating only a very slight deltaic influence.

\section{CONCLUSION}

Detailed analysis of sand fractions and statistical treatment of the data by correspondence analysis reveals the presence of distinctive assemblages within apparently homogeneous sediments in the Rud Hilla delta area of the Persian Gulf. The different facies represented by the assemblages comprise three late Holocene (< approx. 6000 y. B.P.) facies (including a total of 9 subfacies) and three facies of late Pleistocene-early Holocene age. The Holocene sedimentary history is marked by an increase of sedimentation rate, a progradation of the Rud Hilla delta and, therefore, by a migration of facies.

The clear recognition of the identity of the late Holocene facies permits definite comparisons to be made with the earlier facies. The evolution of facies within the Pleistocene sediments corresponds quite closely to the successive changes of late Holocene facies that occur with increasing distance from the sedimentary source. The main contrasts between Pleistocene and Holocene facies could have resulted from differences in climatic and hydrodynamic conditions, and in the nature of the sedimentary source. Correspondence analysis seems to be a tool of considerable promise for quantitative interpretation of the histories of deltaic sedimentary sequences.

\section{ACKNOWLEDGEMENTS}

I thank all those who assisted me during the course of this study. My thanks are most particularly addressed to Professors Seibold and Boillot who suggested that I undertake the research, and for whose guidance and advice I have been very grateful. Dr. Sarnthein introduced me to sand fraction analysis and Mr. Kerbaol to correspondence analysis. Professor Metivier, Miss Le Menn, Mr. Le Faou assisted me with the computer programming. I am very grateful to Dr. H. D. Needham for his generous help and advice on the improvements of the manuscript. The Centre National pour 1'Exploitation des Océans provided financial support. 
TABLE 1. Location and description of sediment cores from the Rud Hilla delta

\begin{tabular}{|c|c|c|c|c|c|c|c|}
\hline CORE $N^{\circ}$ & STATION $\mathrm{N}^{\circ}$ & \multicolumn{3}{|c|}{ LOCATION } & WATER DEPTH & CORE LENGTH & DESCRIPTION \\
\hline 1144 & M $330 / 3$ & $29^{\circ}$ & $01 ' \mathrm{~N}$ & $50^{\circ} 42^{\prime} \mathrm{E}$ & $8 \mathrm{~m}$ & $2 \mathrm{~m}$ & brownish, homogeneous mud $^{+}$ \\
\hline 1143 & M $330 / 2$ & $29^{\circ}$ & $00^{\prime} \mathrm{N}$ & $50^{\circ} 41^{\prime} \mathrm{E}$ & $15 \mathrm{~m}$ & $2 \mathrm{~m}$ & brown-greenish, homogeneous mud \\
\hline 1142 & M $330 / 1$ & $29^{\circ}$ & $00^{\prime} \mathrm{N}$ & $50^{\circ} 39^{\prime} \mathrm{E}$ & $23 \mathrm{~m}$ & $2 \mathrm{~m}$ & greenish, homogeneous mud \\
\hline 1118 & M 309 & $28^{\circ}$ & $36^{\prime} \mathrm{N}$ & $50^{\circ} 56^{\prime} \mathrm{E}$ & $21 \mathrm{~m}$ & $3 \mathrm{~m}$ & greenish, homogeneous mud \\
\hline 1160 & M 345 & $28^{\circ}$ & $32^{\prime} \mathrm{N}$ & $50^{\circ} 54^{\prime} \mathrm{E}$ & $29 \mathrm{~m}$ & $4 \mathrm{~m}$ & greenish, homogeneous mud \\
\hline 1165 & M 348 & $28^{\circ}$ & $07^{\prime} \mathrm{N}$ & $51^{\circ} 00^{\prime} \mathrm{E}$ & $46 \mathrm{~m}$ & $4 \mathrm{~m}$ & greenish, homogeneous mud \\
\hline 1115 & M 306 & $28^{\circ}$ & $22^{\prime} \mathrm{N}$ & $50^{\circ} 40^{\prime} \mathrm{E}$ & $56 \mathrm{~m}$ & $2 \mathrm{~m}$ & $\begin{array}{l}3 \text { distinctive units : } \\
\text { - } 0 \text { - } 40 \mathrm{~cm}: \text { greenish sediment } \\
\text { with large shell fragments. } \\
\text { - } 40-90 \mathrm{~cm}: \text { intermediate units } \\
\text { to interfingering green and } \\
\text { white muds. } \\
\text { - } 90 \text { - } 180 \mathrm{~cm} \text { : very fine and } \\
\text { homogeneous whitish mud. }\end{array}$ \\
\hline
\end{tabular}

+ The term "mud" is used for sediment containing $99 \%$ of particles finer than sand-size ( $<63 \mu)$. 
TABLE 2. C 14 Ages $^{(1)}$ of sediment from the Rud Hilla delta area, Persian Gulf

\begin{tabular}{|l|c|c|}
\hline CORE $\mathrm{N}^{\circ}$ & SAMPLE LEVEL & AGE (years B.P.) \\
\hline 1160 & $0-7 \mathrm{~cm}$ & $975 \pm 260$ \\
& $30-35 \mathrm{~cm}$ & $1560 \pm 175$ \\
& $87-96 \mathrm{~cm}$ & $2335 \pm 120$ \\
& $127-135 \mathrm{~cm}$ & $3340 \pm 195$ \\
& $231-241 \mathrm{~cm}$ & $2450 \pm 170$ \\
& $333-338 \mathrm{~cm}$ & $5080 \pm 185$ \\
& $380-390 \mathrm{~cm}$ & $5840 \pm 200$ \\
& & \\
\hline \multirow{3}{*}{1165} & $0-10 \mathrm{~cm}$ & $1970 \pm 140$ \\
& $187-197,5 \mathrm{~cm}$ & $2250 \pm 135$ \\
& $208-218 \mathrm{~cm}$ & $2195 \pm 215$ \\
& $281-291,5 \mathrm{~cm}$ & $2625 \pm 155$ \\
& $302-307,5 \mathrm{~cm}$ & $3060 \pm 115$ \\
& $315-322 \mathrm{~cm}$ & $3740 \pm 90$ \\
& $322-329 \mathrm{~cm}$ & $4255 \pm 245$ \\
& & \\
\hline \multirow{3}{*}{$1115{ }^{(2)}$} & & \\
\hline & & \\
\hline
\end{tabular}

(1) C 14 ages of total sediment or of shells (determined by Dr. Geyh of the Laboratoire fur Bodenforschung, Hannover).

(2) Age refers to a second correlatable core taken at the same station. 
TABLE 3. Relationship of facies to environmental parameters in the Rud Hilla delta

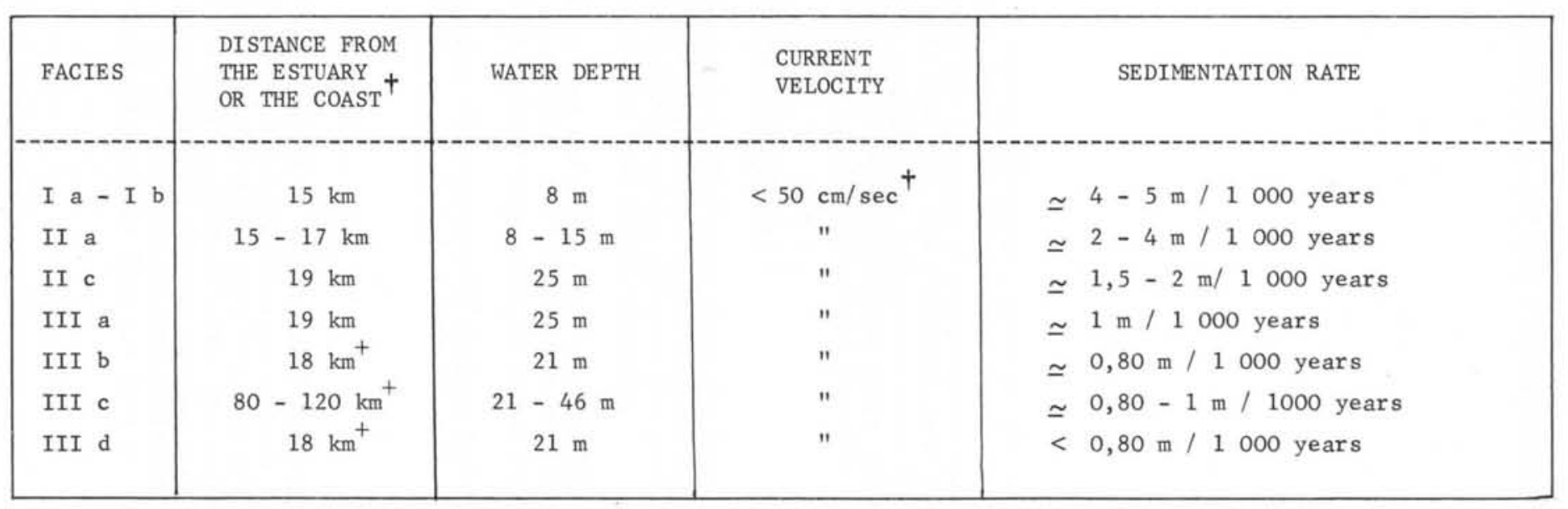

† Near-bottom currents velocity off Buschire (after Peery, 1965). 